University for Business and Technology in Kosovo

UBT Knowledge Center

UBT International Conference

2015 UBT International Conference

Nov 7th, 9:00 AM - 5:00 PM

\title{
The effects of strategic environmental analysis on organizational performance
}

\author{
Enida (Brakaj) Pulaj \\ University Ismail Qemali Vlora, enidapulaj@yahoo.com \\ Ilira Pulaj \\ University Ismail Qemali Vlora, ilira.pulaj@gmail.com
}

Follow this and additional works at: https://knowledgecenter.ubt-uni.net/conference

Part of the Business Commons

\section{Recommended Citation}

Pulaj, Enida (Brakaj) and Pulaj, llira, "The effects of strategic environmental analysis on organizational performance" (2015). UBT International Conference. 27.

https://knowledgecenter.ubt-uni.net/conference/2015/all-events/27

This Event is brought to you for free and open access by the Publication and Journals at UBT Knowledge Center. It has been accepted for inclusion in UBT International Conference by an authorized administrator of UBT Knowledge Center. For more information, please contact knowledge.center@ubt-uni.net. 


\title{
The effects of strategic environmental analysis on organizational performance
}

\author{
Enida Pulaj (Brakaj) ${ }^{1}$, Ilira Pulaj² \\ ${ }^{1}$ University of Vlora, Management Department \\ ${ }^{2}$ University of Vlora, Economics Department \\ enidapulaj@yahoo.com¹,ilira.pulaj@gmail.com²
}

\begin{abstract}
Businesses do not operate in a vacuum. They operate in a dynamic, complex and competitive environment. So, the success and failure of many companies depends on several factors and the possibility to analyze them according the information level. The importance and the priorities of factors analysis vary from one situation to another due to the specific nature of the product and service, company and industry. Therefore, the organizational processes have to be based and adapted to the external environment.

The main purpose of this paper is to critically examine and rank the effects of external environment factors on organizational performance in an industry. The data are collected through a structured questionnaire. The questionnaire includes sections which assess the impact of changes and developments in the external environment. The survey is conducted mainly in Vlora city and randomly in Himara and Orikum. Following the purpose of the study, it has been involved all the construction companies that do business in the city of Vlora and in their construction projects portfolios are involved: infrastructure, residential buildings (living apartments and villas), industrial constructions and other buildings such as hospitals, universities, government buildings, etc.

To analyze the data collected through the questionnaires, we used the statistical test such as mean, median, standard deviation as well as specific weights to rank the evaluation effect of each external factor.This paper reports findings on the relationship between the external factors and the organizational performance. The study found significant positive and negative effects of external factors on performance as well as classifying them in the factors that facilitate or create barriers to business.
\end{abstract}

Keywords: External environment analysis, Construction industry, Organizational performance

\section{Introduction}

The success and the failure of many companies depend on the factors which affect their activities. Without taking into account the impact of environmental factors, it is not possible to plan a good strategy or to manage profitable business. The external environment analysis refers to the factors that are outside the influence and control of the organization. It should be an important part of the decision making process and developing process of competitive strategies. The intensive changes of business conditions are an important fact that the organization operates in a competitive environment characterized by dynamics and complexity (Beal, 2000). It operates as an open system, located in a certain field and connected directly or not with the influence of factors that compose this environment. This paper serves to provide a real analysis of variables as a tool of refining and focusing in a certain industry. We choose construction industry for several reasons. Construction is a very important branch of one country development and it plays an important role especially in today's conditions where the rate of industrialization of this sector is growing fast. The construction industry occupies about $4.3 \%$ of the total active enterprises operating in our country (INSTAT, 2012). It has a significant share of the national GDP and employs hundreds of thousands of people continuously. Certainly, the construction industry is one of the major industries regardless the country where it is studied. This is, due to the high level of goods and services presence in the form of housing, transport and communication in our life 


\section{Overview of external environment analysis}

Today's organizations have to deal with dynamic and uncertain environments. Naturally, the organizational processes, the systems and strategies should be based and adapted to change due to the external environment factors. The dependence on external environment is not a problem in itself, as long as the environment surrounding the company appears static and simple during the analysis of the factors that constitute it. The problem arises when the uncertainty, dynamics and complexity will increase. As complexity increases, the ability to understand, to plan and predict becomes more difficult (Black \& Farias, 1997), requiring an ongoing analysis by the company which can be achieved through detailed analysis of the macro-environment. Although, the early definitions about external environment, we can say that what likely change is the way by which we manage to answer the question: "What areas of external environment need to analyze?

Scanning the external environment where the company operates means to seek, collect and use information about events, trends, relationships between variables and learning process which assist managers during the planning of the future through action (Voros, 2001). Therefore, the companies analyze the environment in order to find and understand the external forces from which they are affected and to respond with appropriate actions ensuring a competitive position as the order of the day (Nistorescu and Barbu, 2006).

The main purpose of this paper is to examine and rank the effects of external environment factors on organizational performance. All the analyzed factors are taken from macro- environment including political-legislative, economic, social and technologic variables. In different management literature, it can be found under the acronym PESTLE analysis and its goal is to develop and explain the impact of any external environmental factor, profitability and overall performance of the company. Multitude of external environment factors can be grouped as follows:

Political environment. The legal framework has a huge influence on the way it regulates business activity, purchasing power of consumers and other businesses. It includes all laws and legal regulations and policy framework refers to the relational system created between political power and business

Economic environment. Economic factors have to do with the nature and direction of the economy in which the company operates (Fahey and Narayanan, 1986). The economy has a significant impact on the company's strategy because it affects the capital cost, the purchasing power of the organization as well as the purchasing power of consumers of goods and services. Also, the level of economic development has a direct impact on the factors which compose this environment (Kume, 2010).

Social environment. Social factors include beliefs, values, attitudes, opinions and lifestyles of individuals as part of the external environment of the company (Wheelen \& Hunger, 1990). Social forces are dynamic and in a continuously process of change as a result of the individuals' efforts to fulfill the desires and needs controlling and adjusting external environmental factors (Kume, 2010).

Technological environment. According Ward and Rivani (2005), technological factors include government spending on research and development, the focus on technological development of industry, innovation, etc. Shrivastava (1995) argues that companies need to update their technologies concluding new and improved standards of technological environmental factors. From this point of view, technological environment helps companies to achieve social as well as economic goals.

The construction industry is the "arena" where this study starts and has been applied but in principle, it remains an applicable model to every industry that needs to be studied. The construction industry is generally characterized as a branch of monopolistic competition where the number of competitive firms forces themselves to behave in a strategic way. Construction is one of the industries which have developed considerably after the year 1991, related to the economic changes in Albania towards a market economy. The market forces and entrepreneurial initiatives, the current state of housing, the public and private needs for infrastructure and a variety of other factors brought as a result a rapid development of the construction sector. However, despite the economic growth and development numerous of this industry, during these years there has been not easy to face challenges. There are challenges that all countries in transition have to face and it needs time in order to minimize their negative effects (Pulaj \& Kume, 2013). Some of the problems and challenges for which the industry has experienced are: constraints with construction permits, the fiscal legislation, the fluctuations of 
consumer demand as a result of the economic crisis, the informal labor market, raw material costs affected by inflation, the level of corruption etc.

The construction industry occupies about $4.3 \%$ of the total active enterprises operating in our country (INSTAT 2012). It has a significant share of the national GDP, employs hundreds of thousands of people continuously. It has been noticed that the number of construction companies entering this industry has increased in the latest years. This increasing tendency has been justified by the economic growth that our country has had, also the increase demands of buying new buildings. In the earlier 90 's, according to a functional land plan, the government as the political adjuster and the only controller of the sources decided where and how the production will get organized and offered, etc,. With the adoption of the economical market, the state lost the monopoly of the only provider of the products and services.

\section{Research methodology}

\subsection{Research methodology}

In the study, it has been involved all the construction companies that do business activity in Vlora region and in their construction projects portfolio are involved: infrastructure, residential buildings (living apartment and villas), industrial constructions and other buildings such as hospitals, universities, government buildings, etc. The data are collected through a structured questionnaire. The questionnaire includes sections which assess the impact of changes and developments in external environment. The survey is conducted mainly in Vlora city and randomly in Himara and Orikum. Table 1 presents the distribution of companies according the year of creation. It is noticed that the participated companies have different longevity beginning from 1992. Almost 32.7\% of sample had over 10 years in this industry till the year 2001 . It is noted that the period between the years 2000 2008 marks the highest number of registered firms due to the development of construction industry and the highest number of building permits approved in the district of Vlora. Weighting the life of surveyed firms, we see the average lifespan in the industry is relatively 7.7 years because of the high number of registered firms in recent years as a result of inducement that offered the industry expressed at high profit rates. The distribution of firms by year of creation is given in the table below:

Table 1 Distribution of firms by year of creation

\begin{tabular}{|c|c|c|c|c|c|c|c|}
\hline Year & Frequency & Percent & $\begin{array}{c}\text { Cumulative } \\
\text { percent }\end{array}$ & Year & Frequency & Percent & $\begin{array}{c}\text { Cumulative } \\
\text { percent }\end{array}$ \\
\hline $\mathbf{1 9 9 2}$ & 1 & 0.9 & 0.9 & $\mathbf{2 0 0 3}$ & 8 & 7.3 & 42.7 \\
\hline 1993 & 2 & 1.8 & 2.7 & $\mathbf{2 0 0 4}$ & 3 & 2.7 & 45.5 \\
\hline 1994 & 2 & 1.8 & 4.5 & $\mathbf{2 0 0 5}$ & 11 & 10.0 & 55.5 \\
\hline $\mathbf{1 9 9 5}$ & 4 & 3.6 & 8.2 & $\mathbf{2 0 0 6}$ & 10 & 9.1 & 64.5 \\
\hline $\mathbf{1 9 9 6}$ & 3 & 2.7 & 10.9 & $\mathbf{2 0 0 7}$ & 12 & 10.9 & 75.5 \\
\hline $\mathbf{1 9 9 8}$ & 5 & 4.5 & 15.5 & $\mathbf{2 0 0 8}$ & 13 & 11.8 & 87.3 \\
\hline $\mathbf{1 9 9 9}$ & 3 & 2.7 & 18.2 & $\mathbf{2 0 0 9}$ & 7 & 6.4 & 93.6 \\
\hline $\mathbf{2 0 0 0}$ & 7 & 6.4 & 24.5 & $\mathbf{2 0 1 0}$ & 5 & 4.5 & 98.2 \\
\hline $\mathbf{2 0 0 1}$ & 9 & 8.2 & 32.7 & $\mathbf{2 0 1 1}$ & 2 & 1.8 & 100.0 \\
\hline $\mathbf{2 0 0 2}$ & 3 & 2.7 & 35.5 & Total & 110 & 100.0 & \\
\hline
\end{tabular}

Table 2 presents the distribution of companies according the employees number. 43 companies (39.1\% of total) have fewer than 10 employees. The majority of the sample, approximately $55.5 \%$ of the companies have between 10-49 employees and only 5.5\% of companies declared the number of employees between 50-249 employees. One of the main reasons for the high number of construction firms, registered as a small and the medium companies is the subcontracting process of works by other companies that offer specialized services. 
Table 2. Distribution of firms by number of employees

\begin{tabular}{|l|c|c|c|}
\hline Employees number & Frequency & Percent & Cumulative percent \\
\hline $1-9$ employees & 43 & 39.1 & 39.1 \\
\hline $10-49$ employees & 61 & 55.5 & 94.5 \\
\hline $50-249$ employees & 6 & 5.5 & 100.0 \\
\hline Total & 110 & 100.0 & \\
\hline
\end{tabular}

According the data gathered from the questionnaires, the geographical distribution of the companies is mainly in Vlora, Orikum and Himara Municipalities, covering all areas where construction industry had the higher development period, including both urban area and coastline. Most of the firms perform their activities in Vlora, while only $8.2 \%$ in Orikum and $2.7 \%$ in Himara. Discussing the distribution of companies by the construction projects included in their portfolio, it is noted that most of the works and projects, nearly $86.4 \%$ of the sample size, belong to the private sector such as residential, commercial and industrial construction (houses and apartments). Only $13.6 \%$ of the projects belong to public sector such as infrastructure (roads, tunnels, bridges, airports) and institutional constructions (schools, hospitals, etc).

\section{Descriptive analysis of the construction industry based on external environment variables}

In addition to the main purpose of this paper, descriptive analysis was used to rank the effects of external environment factors on organizational performance in an industry. The data are collected through a structured questionnaire. The questionnaire includes sections covering the impact of changes and developments in the external (macro) environment to classify them into mitigating factors or barriers to exercise the business activity.

Based on a Likert scale, each statement applied a Likert scale ranging from 1 to 5 to every factor/variable of economic, politic, social and technological environment, identifying how significant/important they were to either industry or organizational performance. A value of 1 indicated that the associated factor possessed little or no significance while a value of 5 indicated that the factor was highly significant $(1=$ not important, $2=$ less important, $3=$ =neutral, $4=$ important, $5=$ very important). According the respondents opinion, economic factors with the greatest impact are: the disposable revenues and changes in the propensity to buy (median of 5.00), followed by changes in interest rate and changes in the exchange rate (respective median 4.00 and 3.00). The values from each statement are processed in the Table 3 . The propensity to buy, as important factor of economic environment, presents which customers are ready to make their purchase: so the company can find who to target. Moreover, once it is known who is ready and who is not helps the firms to provide the right influence in their offer. Albania is a middle income country by Western European standards and remittances constitute a very important income for Albanian families. A significant part of these families with low incomes, have remittances as a vital source which in most cases goes to utility products and services.

Table 3. The impact of macro-economic variables

\begin{tabular}{lcccc}
\hline $\begin{array}{l}\text { Changes in macro-economic } \\
\text { environment }\end{array}$ & Mean & Median & $\begin{array}{c}\text { Standard } \\
\text { Deviation }\end{array}$ & $\begin{array}{c}\text { Coefficient } \\
\text { of Variation }\end{array}$ \\
\hline Changes in propensity to buy & 4.49 & 5.00 & 0.723 & 0.163 \\
\hline Changes in exchange rate & 3.15 & 3.00 & 1.233 & 0.391 \\
\hline Changes in interest rate & 3.53 & 4.00 & 1.179 & 0.334 \\
\hline Changes in disposable revenue & 4.37 & 5.00 & 0.776 & 0.178 \\
\hline
\end{tabular}

$\square$ The same analysis of resulted value is done also for the political and legislative variables. Based on a Likert scale, each statement applied a ranging from 1 to 5 to every factor/variable identifying how significant/important the political environment is to organizational performance. A value of 1 indicated that the associated factor possessed little or no significance while a value of 5 indicated that the factor was highly significant $(1=$ not important, $2=$ less important, $3=$ =neutral, $4=$ important, $5=$ very important). According the respondents opinions, Table 4 shows the factors with the greatest 
impact changed recently in the political and legal environment: (1) the time to be spent by executives of construction firms for different applications in state institutions (procurement, building permit) (median score of 5.00), followed by the impact of correct interpretation of law, the impact of changes in market regulation and competition law, impact of irregularities faced in obtaining building permit, lack of urban regulatory plans and urban planning law (all with median score of 4.00 ). The remaining items assumed moderate and low importance (i.e. the impact of changes in labour market law, the impact of changes in public spending, and the impact of changes in international trade regulations). Although, it has been made a significant improvement referred to the reform about the procedures for application and securing building permits, it is worth noting, that the time spent and uncertainty on property rights remain the factors that still hamper the activity of construction firms. The deficiencies, the bureaucracy and the ambiguity of the property restitution law, the inability to return them in production and service facilities, the weak institutional support for transforming them into effective and productive assets, are the obstacles to a well functioning of the construction sector and contributing to a high number of non-regular buildings. According to ALUIZNI statistics, there are registered 270.592 illegal buildings by 2007 and 22.570 from 2007-2013. Beyond this fact, the regulatory plan was a rigid instrument which continued to promote informality. Meanwhile, some of the laws, which were subject of frequent changes, aiming their applicability, brought more uncertainty by creating delays during building permit procedures. The remaining items assumed medium and low importance respectively: The impact of changes in public spending, The impact of changes in labour market law (median score of 3.00) and The impact of changes in international trade regulations (median score of 1.00). It is noted that the impact of changes in public spending has a medium impact on organizational performance due to the high focus of respondent firms in private sector (residential, commercial and industrial construction). As stated in sample demographics topic, nearly $86.4 \%$ of the sample size belongs to the private sector and only $13.6 \%$ of them deal with public projects such as infrastructure (roads, tunnels, bridges, airports) and institutional constructions (schools, hospitals, etc).

Table 4. The impact of political and legal environment

\begin{tabular}{lcccc}
\hline Changes in political environment & Mean & Median & $\begin{array}{c}\text { Standard } \\
\text { Deviation }\end{array}$ & $\begin{array}{c}\text { Coeff. of } \\
\text { Variation }\end{array}$ \\
\hline $\begin{array}{l}\text { The impact of changes in market regulation } \\
\text { and competition law }\end{array}$ & 4.01 & 4.00 & 0.991 & 0.247 \\
\hline The impact of changes in labour market law & 3.42 & 3.00 & 0.783 & 0.229 \\
\hline The impact of changes in public spending & 2.62 & 3.00 & 1.109 & 0.423 \\
\hline $\begin{array}{l}\text { The impact of changes in international trade } \\
\text { regulations }\end{array}$ & 2.05 & 1.00 & 1.340 & 0.653 \\
\hline $\begin{array}{l}\text { The impact of correct interpretation of law } \\
\text { Time to be spent by executives of construction } \\
\text { firms for different applications in state } \\
\text { institutions (procurement, construction } \\
\text { permits etc.) }\end{array}$ & 4.49 & 4.00 & 1.059 & 0.279 \\
\hline $\begin{array}{l}\text { Impact of irregularities faced in obtaining } \\
\text { building permit }\end{array}$ & 4.05 & 4.00 & 0.962 & 0.180 \\
\hline $\begin{array}{l}\text { Lack of urban regulatory plans and urban } \\
\text { planning law }\end{array}$ & 3.94 & 4.00 & 1.111 & 0.282 \\
\hline
\end{tabular}

$\square$ Based on the socio-cultural environment, there are used two of the variables referred: the impact of changes in investment preferences by individuals and the impact of demographic changes, age and population growth. According the respondents opinions, Table 5 shows the both variables equally important. 
Table 5. The impact of social environment

\begin{tabular}{lcccc}
\hline $\begin{array}{l}\text { Changes in } \\
\text { social environment }\end{array}$ & Mean & Median & $\begin{array}{l}\text { Standard } \\
\text { Deviation }\end{array}$ & $\begin{array}{c}\text { Coeff. of } \\
\text { variation }\end{array}$ \\
\hline $\begin{array}{l}\text { The impact of changes in } \\
\begin{array}{l}\text { investment preferences by } \\
\text { individuals and families }\end{array}\end{array}$ & 3.78 & 4.00 & 0.913 & 0.242 \\
\hline $\begin{array}{l}\text { The impact of demographic } \\
\text { changes, age and population } \\
\text { growth }\end{array}$ & 3.65 & 4.00 & 0.904 & 0.247 \\
\hline
\end{tabular}

The orientation of savings and remittances income toward real estate is a significant factor on the construction industry analysis. The trends to invest in real estate as a secure investment, are reflected in developments that immobiliare sector has had during the recent years. Another important variable to all firms operating in this industry is the demographic changes and population growth. The construction industry must take into account the changing needs of the population in its construction projects such as building design and structure (CIOB, 2009). It's not just homes that need to be adapted to ensure a safe and inclusive environment, but also the wider surroundings. After the years 2000-2001, with the normalization of demographic movement towards urban centers, there is a stabilization of demography with the exception of the coastal cities where the demand for tourism infrastructure remains a priority for the regional development of these centers. Focusing on the needed infrastructures and residential sector in accordance with the demographic changes is the essence of social environment and has an important impact of industry development.

$\square$ Although, Albania is a new country in the field of technological development, there has been a significant improvement in the area of investments made for the technological environment. Conducting business electronically, as a form of business organization, it means the use of information, especially the Internet, for the implementation of all core business functions. These environmental factors have contributed to the awareness of the Albanian businesses to increase technological investment using new services that facilitate contacts and assist in the expansion of business activity worldwide. Based on a Likert scale ranging from 1 to $5(1=$ not important, $5=$ very important), the respondents answers are shown at the Table 6. According their responses, technological variables included in this study are ranked: (1) changes and development of new production technologies (median score of 4.00), (2) changes and development of internal IT applications, (3) the impact of technological changes and e commerce development (median score of $3.00)$.

Table 6. The impact of technological environment

\begin{tabular}{l|c|c|c|c}
\hline $\begin{array}{l}\text { The impact of technological } \\
\text { environment }\end{array}$ & Mean & Median & $\begin{array}{c}\text { Standard } \\
\text { Deviation }\end{array}$ & $\begin{array}{c}\text { Coeff. of } \\
\text { Variation }\end{array}$ \\
$\begin{array}{l}\text { The impact of technological } \\
\text { changes and e commerce } \\
\text { development }\end{array}$ & 2.88 & 3.00 & 1.139 & 0.395 \\
\hline $\begin{array}{l}\text { Changes and development of } \\
\text { internal IT applications }\end{array}$ & 2.90 & 3.00 & 1.083 & 0.373 \\
\hline $\begin{array}{l}\text { Changes and development of } \\
\text { new production technologies }\end{array}$ & 3.66 & 4.00 & 1.069 & 0.292 \\
\hline
\end{tabular}

In summary, the comparative analysis of external environmental factors is presented in Table 7. Besides comparing the average value, median and standard deviation, the analysis of external environment also compares the specific weight value of each factor to the total of factors considered in the study.

It is noted that the factors with the highest impact compared to others are: (i) changes in propensity to buy (ii) the time to be spent by executives of construction firms for different applications in state institutions (procurement, construction permits) (iii) changes in disposable revenue, (iv) impact of irregularities faced in obtaining building permit, (v) the impact of changes in market regulation and competition law; (vi) lack of urban regulatory plans and urban planning law. Factors with the lowest 
impact compared to others are: changes and development of internal IT applications and the impact of changes in international trade regulations. Based on the analysis of the external environment, the factors with the highest impact in the construction industry belong to the concerns faced by construction companies.

Table 7. Numeric characteristics of each external variable

\begin{tabular}{|l|c|c|c|c|c|c|}
\hline External environment variables & Mean & Median & $\begin{array}{c}\text { Std. } \\
\text { Deviation }\end{array}$ & Min & Max & $\begin{array}{c}\text { Specific } \\
\text { weight }\end{array}$ \\
\hline Changes in propensity to buy & $\mathbf{4 . 4 9}$ & $\mathbf{5 . 0 0}$ & $\mathbf{. 7 2 3}$ & $\mathbf{1}$ & $\mathbf{5}$ & $\mathbf{0 . 0 7 4}$ \\
\hline Changes in exchange rate & 3.15 & 3.00 & 1.233 & 1 & 5 & 0.052 \\
\hline Changes in interest rate & 3.53 & 4.00 & 1.179 & 1 & 5 & 0.058 \\
\hline Changes in disposable revenue & $\mathbf{4 . 3 7}$ & $\mathbf{5 . 0 0}$ & $\mathbf{. 7 7 6}$ & $\mathbf{1}$ & $\mathbf{5}$ & $\mathbf{0 . 0 7 2}$ \\
\hline $\begin{array}{l}\text { The impact of changes in market } \\
\text { regulation and competition law }\end{array}$ & $\mathbf{4 . 0 1}$ & $\mathbf{4 . 0 0}$ & $\mathbf{. 9 9 1}$ & $\mathbf{2}$ & $\mathbf{5}$ & $\mathbf{0 . 0 6 6}$ \\
\hline $\begin{array}{l}\text { The impact of changes in labour } \\
\text { market law }\end{array}$ & 3.42 & 3.00 & .783 & 2 & 5 & 0.056 \\
\hline $\begin{array}{l}\text { The impact of changes in public } \\
\text { spending }\end{array}$ & 2.62 & 3.00 & 1.109 & 1 & 5 & 0.043 \\
\hline $\begin{array}{l}\text { The impact of changes in international } \\
\text { trade regulations }\end{array}$ & 2.05 & 1.00 & 1.340 & 1 & 5 & 0.034 \\
\hline $\begin{array}{l}\text { The impact of correct interpretation of } \\
\text { law }\end{array}$ & 3.79 & 4.00 & 1.059 & 1 & 5 & 0.062 \\
\hline $\begin{array}{l}\text { Time to be spent by executives of } \\
\text { construction firms for different } \\
\text { applications in state institutions. }\end{array}$ & $\mathbf{4 . 4 9}$ & $\mathbf{5 . 0 0}$ & $\mathbf{. 8 1 0}$ & $\mathbf{2}$ & $\mathbf{5}$ & $\mathbf{0 . 0 7 4}$ \\
\hline $\begin{array}{l}\text { Impact of irregularities faced in } \\
\text { obtaining building permit }\end{array}$ & $\mathbf{4 . 0 5}$ & $\mathbf{4 . 0 0}$ & $\mathbf{. 9 6 2}$ & $\mathbf{1}$ & $\mathbf{5}$ & $\mathbf{0 . 0 6 7}$ \\
\hline $\begin{array}{l}\text { Lack of urban regulatory plans and } \\
\text { urban planning law }\end{array}$ & $\mathbf{3 . 9 4}$ & $\mathbf{4 . 0 0}$ & $\mathbf{1 . 1 1 1}$ & $\mathbf{1}$ & $\mathbf{5}$ & $\mathbf{0 . 0 6 5}$ \\
\hline $\begin{array}{l}\text { The impact of changes in investment } \\
\text { preferences by individuals }\end{array}$ & 3.78 & 4.00 & .913 & 1 & 5 & 0.062 \\
\hline $\begin{array}{l}\text { The impact of demographic changes, } \\
\text { age and population growth }\end{array}$ & 3.65 & 4.00 & .904 & 1 & 5 & 0.060 \\
\hline $\begin{array}{l}\text { The impact of technological changes } \\
\text { and e commerce development }\end{array}$ & 2.88 & 3.00 & 1.139 & 1 & 5 & 0.047 \\
\hline $\begin{array}{l}\text { Changes and development of internal } \\
\text { IT applications }\end{array}$ & 2.90 & 3.00 & 1.083 & 1 & 5 & 0.048 \\
\hline $\begin{array}{l}\text { Changes and development of new } \\
\text { production technologies }\end{array}$ & 3.66 & 4.00 & 1.069 & 1 & 5 & 0.060 \\
\hline
\end{tabular}

In the context of the external environment analysis, companies were asked about the factors that hamper the activity and performance of the company towards achieving the required objectives. Respondents were next asked to rank the three variables that most affect firm performance. Table 8 presents the aggregated scores, which resulted from checking the variables according the barriers they represent to the business activity. The financial problems and the lack of liquidity remain the main restrictive factors in construction activity. These factors are considered as restrictive variables and hamper the activity of a large number of companies. As can be seen, the final ranking was the following: 81 times is considered as a prohibitive factors the financial problems and lack of liquidity. However, the survey results report that another limitation or difficulties faced by these companies is related to administrative obstacles of legal character, such as unfair competition, the informal market and the procedure to request a building permit. Other limiting factor is the difficulty to take loans from financial institutions (banks). Many construction companies are registered and categorized as small and medium enterprises that appear more riskless than large companies/corporations. Moreover, the declining demand and the decrease sales rated the construction sector to be less reliable by banks. Two other factors distinguished from construction firms, are: the lack of demand and incorrect implementation of procurement law. The stagnation of demand refers to the low level of disposable income and the public investment reduction. Also, procurement law and "favoritism" of some of the companies compared to others has been seen as another barrier for companies that operate in this industry. 
Table 8. Barriers of construction activities

\begin{tabular}{|l|c|}
\hline Barrier & Point \\
\hline Financial problems & 81 \\
\hline Unfair competition from informal market & 60 \\
\hline The procedure to request a building permit & 49 \\
\hline Difficulties to take loans & 32 \\
\hline Lack of demand & 22 \\
\hline Tax law application failure & 22 \\
\hline Procurement law application failure & 19 \\
\hline Unclear fiscal legislation & 16 \\
\hline Lack of infrastructure (roads, railways) & 10 \\
\hline Unexpected occurrence in macro-economic environment & 9 \\
\hline Others (subcontractors agreement) & 7 \\
\hline
\end{tabular}

Source: Authors calculation from questionnaire data collected

It is noted that organizations must be able to understand the complexity and the dynamics of external environment trends. Organizations must be able to manage changes successfully involving:

$\checkmark \quad$ a clear awareness of environmental forces and the ways in which they are changing

$\checkmark \quad$ an appreciation of potential and future threats and opportunities

$\checkmark \quad$ a clear definition about the right targeted market

\section{References}

1. Beal, R.B. (2000). Competing Effectively; Environmental Scanning, Competitive Strategy, and Organizational Performance in Small Manufacturing Firms, Journal of Small Business Management, Vol 38, (I), pp. 27-47

2. Black, J. and Farias, G. (1997), "Genesis of complexity cycles", paper presented at 8th Annual International Conference of The Society for Chaos Theory in Psychology and Life Sciences, Boston University, Boston, MA, 31 July

3. CIOB-Chartered Institute of Building, 2009. The impact of the ageing population on the construction industry. Retrieved on line at https://www.ciob.org/sites/default/files/CIOB\%20research\%20-

\%20The $\% 20$ Impact $\% 20$ of $\% 20$ the $\% 20$ Ageing $\% 20$ Population $\% 20$ on $\% 20$ the $\% 20$ Construction $\% 2$ 0Industry_0.pdfvan

4. Fahey, L. and Narayanan, V.K. (1986). Macro environmental analysis for strategic management. The West Series in Strategic Management). St. Paul, Minnesota: West Publishing Company.

5. Kume, V. (2010). Menaxhimi strategjik. Teori, koncepte, zbatime. Tirane.

6. Nistorescu, T. and Barbu, M.C.(2006). A model for enterprises' environmental scanning. Management and marketing journal. Vol 4(1), pp. 57-62

7. Pulaj, E. \& Kume, V. (2013). How the Albanian external environment affect the construction industry. Annales Universitatis Apulensis Series Oeconomica, Vol 15(1), pp. 295-309

8. Shrivastava, P. (1995). The Role of Corporations in Achieving Ecological Sustainability. The academy of management review. Vol 20(4), pp. 936-960.

9. Voros, J. (2001). "Reframing environmental scanning: an integral approach". Retrieved on line from http://choo.fis.utoronto.ca/FIS/respub/AFI.pdf

10.Ward, D and Rivani, E. (2005). An Overview of Strategy Development Models and the WardRivani Model. Economics Working Papers

11.Wheelen, T.L., \& Hunger J.D. (2002). Strategic management and business policy. 8th Edition Prentice Hall. Michalewicz, Z.: Genetic Algorithms + Data Structures = Evolution Programs. 3rd ed. Springer-Verlag, Berlin Heidelberg New York (1996) 